\title{
DESCRIPTIVE ANALYSIS OF REAL-WORLD MEDICATION PATTERNS AND ONE-YEAR OUTCOMES OF ACUTE CORONARY SYNDROME PATIENTS WITH METABOLIC SYNDROME IN A TERTIARY CARE HOSPITAL
}

\author{
PRISCILLA PAȘC ${ }^{1,2}$, DANIELA ELISABETA BERDEA ${ }^{1}$, LUCIANA DOBJANSCHI ${ }^{1}{ }^{*}$, \\ CLAUDIA TEODORA JUDEA-PUSTA ${ }^{1}$, MIRCEA IOACHIM POPESCU ${ }^{1,2}$
}

${ }^{I}$ Faculty of Medicine and Pharmacy, University of Oradea, Oradea, Romania

${ }^{2}$ Emergency County Clinical Hospital of Oradea, Oradea, Romania

*corresponding author: dobjanschil@yahoo.com

Manuscript received: October 2020

\begin{abstract}
The prognostic association between metabolic syndrome (MS) and long-term survival of patients with acute coronary syndrome (ACS) in the era of intervention revascularization and high-precision medication had not yet been fully established. The latest ACS guidelines recommend the combined drug regimen, comprising acetylsalicylic acid (ASA), $\mathrm{P}_{2} \mathrm{Y}_{12}$ (purinergic receptor P2Y12) inhibitors, angiotensin-converting enzyme inhibitor (ACE-I) or angiotensin II receptor blocker (ARB), $\beta$ blocker, and statin, to reduce recurrent ischemic cardiovascular events and mortality. The present study examined the prescription patterns of ACS long term-therapies among MS patients and analysed the association between guidelines medication and major adverse events. $49.44 \%$ of ACS patients included in this study received all five guidelinerecommended medications. Deaths occurred predominantly in MS patients receiving less medication, meanwhile major ischemic and bleeding events increased statistically with the number of drug combinations.
\end{abstract}

\section{Rezumat}

Asocierea prognostică dintre sindromul metabolic (SM) și supraviețuirea pe termen lung a pacienților cu sindrom coronarian acut (SCA) în era revascularizării intervenționale și a medicației de înaltă precizie nu a fost încă pe deplin stabilită. Cele mai recente ghiduri de tratament pentru SCA recomandă regimul combinat de medicamente, cuprinzând acid acetilsalicilic, inhibitor de P2Y12, inhibitor al enzimei de conversie a angiotensinei sau blocant al receptorilor angiotensinei II, $\beta$-blocant și statină, pentru a reduce evenimentele cardiovasculare ischemice recurente şi mortalitatea. Prezentul studiu a examinat tiparele medicamentoase prescrise pentru evenimentul coronarian acut și a analizat asocierea dintre medicația de ghid și evenimentele adverse majore în rândul pacienților cu sindrom metabolic. 49,44\% dintre pacienții cu SCA incluṣi în acest studiu au primit toate cele cinci clase de medicamente recomandate de către ghidurile clinice actuale. Decesele au fost mai frecvente în rândul pacienților cu SM cărora li s-a prescris cea mai puțină medicație, în timp ce evenimentele ischemice și hemoragice majore au crescut statistic cu numărul combinațiilor medicamentoase.

Keywords: metabolic syndrome, acute coronary syndrome, drug prescription patterns

\section{Introduction}

Cardiometabolic syndrome (CMS) is a combination of metabolic dysfunctions that include central obesity associated with insulin resistance, dyslipidaemia, or high blood pressure. Each component is considered an independent risk factor for the cardiovascular atherosclerotic disease, but clustering together they become synergistic, increasing the risk of developing cardiovascular disease greater.

The International Diabetes Federation (IDF) estimates that $20-25$ percent of the world's adult population has metabolic syndrome, and its prevalence in patients with acute coronary syndrome is estimated at $41-50 \%$ in Europe and the United States [10]. Thus, patients with metabolic syndrome have a three-fold higher risk for heart attack or stroke, which demonstrates more advanced coronary artery disease (CAD) and more metabolic and inflammatory abnormalities than patients without MS. The results of a large national survey on the prevalence of overweight/obesity, abdominal obesity and metabolic syndrome and atypical cardiometabolic phenotypes in the adult Romanian population (PREDATORR study) revealed an increased cardiometabolic risk profile in participants with metabolic syndrome [20]. Moreover, the presence of metabolic syndrome in patients with acute coronary syndrome is an important outcome predictor in terms of short and long term mortality. Previous studies have shown increased rates of cardiovascular complications and worse longterm outcomes in ACS patients with MS. Therefore, identifying cardiometabolic risk factors in ACS has 
the potential to improve risk stratification and management of these patients [9].

According to the latest European Society of Cardiology (ESC) guidelines for the management of acute coronary syndrome [7, 8], long-term therapies are recommended in order to reduce the recurrence of ischemic cardiovascular events and to improve the quality of life in patients with ACS. The European Society of Cardiology guidelines recommend early myocardial reperfusion followed by long-term drug therapies including acetylsalicylic acid, P2Y12 inhibitors, angiotensin-converting enzyme inhibitor or angiotensin II receptor blocker, beta-blocker, and statin. Thus, antiplatelet therapy, lipid-lowering therapy, beta-blockade and renninangiotensin blockade are essential for improving long-term prognosis, demonstrated by a large body of evidence showing the beneficial effects of this drug therapies. However, the effects of ACS evidencebased pharmacotherapy in patients with metabolic syndrome on outcomes in real life are largely still unknown.

Therefore, the objectives of the present study were, firstly, to examine the prescription drug patterns of long-term therapy in ACS patients and, secondly, to analyse the association between metabolic abnormalities, guidelines medication and major adverse events in a comprehensive real-world population.

\section{Materials and Methods}

\section{Materials}

This study was conducted at the Emergency Clinical County Hospital of Oradea, North-Western, Romania. An active surveillance of 629 adult admitted patients was performed between January 2018 and December 2019. Patients data were deidentified and encoded anonymously before analysis.

Study population. The study population consisted of all adult patients hospitalized for acute coronary syndrome during $1^{\text {st }}$ January 2018 and $31^{\text {st }}$ December 2018 and followed up for a minimum of 12 calendar months starting the date of discharge.

Data collection and processing

The main inclusion criteria were the presence of acute coronary syndrome diagnosed by characteristic ischemic symptoms, electrocardiographic (ECG) signs of myocardial ischemia and cardiac biomarker (troponin I) status. Furthermore, based on electrocardiographic findings and troponin level (hospital cut-off point of $26 \mathrm{ng} / \mathrm{L}$ ) patients were classified as having STElevation Myocardial Infarction (STEMI), Non-ST Segment Elevation Myocardial Infarction (NSTEMI) or Unstable Angina (UA).

Demographic characteristics (date of birth, age, sex, height, weight, body mass index) were collected as well as the presence of cardiovascular risk factors such as diabetes, hypertension, dyslipidaemia, renal failure, obesity, alcohol consumption and smoking.
Alcohol consumption more than 1 drink per day and smoking of more than 10 cigarettes per day were considered significant. The presence of diabetes was diagnosed as fasting blood glucose $>126 \mathrm{mg} / \mathrm{dL}$ (7 $\mathrm{mmol} / \mathrm{L})$ on repeated determinations or history of diabetes. Hypertension was defined as blood pressure over 140/90 $\mathrm{mmHg}$ or as history of hypertension/ antihypertensive medication. Patients were diagnosed with dyslipidaemia if they had at least one lipid disorder: total cholesterol $>200 \mathrm{mg} / \mathrm{dL}$ or low density lipoprotein cholesterol $(\mathrm{LDLc})>130 \mathrm{mg} / \mathrm{dL}$, triglyceride level $>150 \mathrm{mg} / \mathrm{dL}$ or high density lipoprotein cholesterol (HDLc) level < $40 \mathrm{mg} / \mathrm{dL}(1.03 \mathrm{mmol} / \mathrm{L})$ in males, < $50 \mathrm{mg} / \mathrm{dL}(1.29 \mathrm{mmol} / \mathrm{L})$ in females. LDL cholesterol was estimated by the Friedewald equation. When triglycerides were $>400 \mathrm{mg} / \mathrm{dL}$, LDL cholesterol was measured directly using an automated spectrophotometric assay. Chronic kidney disease was defined as estimated glomerular filtration rate $<60 \mathrm{~mL} / \mathrm{min}$ per $1.73 \mathrm{~m}^{2}$ (estimated glomerular filtration rate calculated using the Chronic Kidney Disease Epidemiology Collaboration equation).

Furthermore, patients were classified by the presence or absence of MS. The International Diabetes Federation consensus worldwide definition of the metabolic syndrome (2006) was used to diagnose MS. Central obesity (defined as waist circumference with ethnicityspecific values) and any two of the following criteria are required for the diagnosis of MS: raised triglycerides: > $150 \mathrm{mg} / \mathrm{dL}(1.7 \mathrm{mmol} / \mathrm{L})$, or specific treatment for this lipid abnormality, reduced HDL cholesterol: < 40 $\mathrm{mg} / \mathrm{dL}(1.03 \mathrm{mmol} / \mathrm{L})$ in males, $<50 \mathrm{mg} / \mathrm{dL}(1.29$ $\mathrm{mmol} / \mathrm{L})$ in females, or specific treatment for this lipid abnormality, raised blood pressure (BP): systolic $\mathrm{BP} \geq 130$ or diastolic $\mathrm{BP} \geq 85 \mathrm{~mm} \mathrm{Hg}$, or treatment of previously diagnosed hypertension or raised fasting plasma glucose (FPG): > $100 \mathrm{mg} / \mathrm{dL}$ (5.6 mmol/L), or previously diagnosed type 2 diabetes. The present consensus specifies that central obesity can be assumed and waist circumference does not need to be measured if body mass index (BMI) is $>30 \mathrm{~kg} / \mathrm{m}^{2}$, so that central obesity was defined at a BMI over 30 in the present study.

Information on underlying diseases such as ischemic heart disease, coronary artery bypass graft (CABG), percutaneous coronary intervention (PCI) and stroke were recorded. The treatment strategies including drug treatment, PCI, CABG as well as echocardiographic data, complications and outcomes were described. Regarding the guidelines medication administered during hospitalization and recommended at discharge, data on combined prescription of the following five drugs: acetylsalicylic acid, P2Y12 inhibitors (Clopidogrel and Ticagrelor), $\beta$-blocker, ACE-I or ARB, and statin were collected.

All major adverse cardiovascular events occurring from the time of hospitalization to 1 year of followup including deaths, major cardiovascular ischemic 
FARMACIA, 2021, Vol. 69, 3

events and bleeding events were described. Major ischemic events consisted in acute coronary events and stroke. Acute coronary events were defined as new troponin elevation with either new onset chest pain/discomfort or ECG changes and stroke was identified using computed tomogram scan. A major bleeding event was defined as a symptomatic bleeding into a critical area or organ (intracranial, gastrointestinal, retroperitoneal) associated with a decrease in haemoglobin of $\geq 2.0 \mathrm{~g} / \mathrm{L}$ or requiring transfusion of $\geq 2$ U.

Statistical analysis. Demographic variables and clinical characteristics of patients selected in this study as well as prescribing rates were examined using descriptive statistics. Frequencies (n) and percentages $(\%)$ were utilized to present categorical variables, whereas mean and standard deviation were used for continuous variables. Normally distributed data were analysed using the Student t-test to compare means. The correlation degrees ( $\mathrm{r}$ ) between the studied parameters were evaluated by calculating the Pearson correlation coefficient. $\mathrm{p}<0.05$ was considered to be statistically significant.

\section{Results and Discussion}

A total of 629 patients with acute coronary syndrome were admitted during the study period. The study cohort was made of STEMI (36.88\%), NSTEMI (33.38\%) and UA (29.72\%) patients. The total prevalence of MS using International Diabetes Federation criteria was $52.30 \%$ (329 patients). The most frequent component of MS was central obesity, as BMI over $30 \mathrm{~kg} / \mathrm{m}^{2}$ was the main criteria for defining metabolic syndrome, followed by reduced HDLc levels, hypertension, hypertriglyceridemia and carbohydrate metabolism disorder in last place. A comparative analysis of patients with and without metabolic syndrome was further made.

Comparative analysis of patients with and without Metabolic Syndrome

Demographic characteristics

Table I summarizes the characteristics of ACS patients participating in the study. Four hundred and thirtyone $(68.68 \%)$ patients were males and $198(31.31 \%)$ were females.

Table I

Characteristics of patients with acute coronary syndrome according to the presence or absence of metabolic syndrome

\begin{tabular}{|c|c|c|c|}
\hline Variable & With MS (n = 329) & Without MS $(n=300)$ & p-value \\
\hline Age (year), mean \pm SD & $63.56 \pm 9.39$ & $66.91 \pm 10.34$ & - \\
\hline$<40, \mathrm{n}(\%)$ & $8(2.43)$ & $8(2.67)$ & - \\
\hline $41-50, \mathrm{n}(\%)$ & $39(11.85)$ & $25(8.33)$ & - \\
\hline $51-60, \mathrm{n}(\%)$ & $77(23.40)$ & $56(18.67)$ & - \\
\hline $61-70, \mathrm{n}(\%)$ & $111(33.74)$ & $81(27.00)$ & - \\
\hline$>71-80, \mathrm{n}(\%)$ & $72(21.88)$ & $82(27.33)$ & - \\
\hline$>80, \mathrm{n}(\%)$ & $22(6.69)$ & $48(16.00)$ & - \\
\hline \multicolumn{4}{|l|}{ Sex } \\
\hline Female, n (\%) & $113(34.35)$ & $85(28.33)$ & - \\
\hline Male, n (\%) & $216(65.65)$ & $215(71.67)$ & - \\
\hline $\mathrm{BMI}\left(\mathrm{kg} / \mathrm{m}^{2}\right)$, mean $\pm \mathrm{SD}$ & $33.71 \pm 2.76$ & $25.55 \pm 3.65$ & - \\
\hline \multicolumn{4}{|l|}{ Type of ACS } \\
\hline NSTEMI, n (\%) & $109(33.13)$ & $101(33.67)$ & 0.886 \\
\hline STEMI, n (\%) & $110(33.43)$ & $122(40.67)$ & 0.060 \\
\hline Unstable angina, $\mathrm{n}(\%)$ & $110(33.43)$ & $77(25.67)$ & 0.034 \\
\hline \multicolumn{4}{|l|}{ Risk factors } \\
\hline Diabetes, n (\%) & $168(51.07)$ & $38(12.67)$ & $<0.001$ \\
\hline Hypertension, $\mathrm{n}(\%)$ & $256(77.81)$ & $121(40.33)$ & $<0.001$ \\
\hline Dyslipidaemia, n (\%) & $314(95.44)$ & $201(67.00)$ & $<0.001$ \\
\hline Renal failure, $\mathrm{n}(\%)$ & $102(31.00)$ & $73(24.33)$ & 0.063 \\
\hline Obesity, n (\%) & $329(100.00)$ & $65(21.67)$ & $<0.001$ \\
\hline Current smoker, n (\%) & $52(15.81)$ & $52(17.33)$ & 0.609 \\
\hline Alcohol consumption, $\mathrm{n}(\%)$ & $13(3.95)$ & $15(5.00)$ & 0.524 \\
\hline \multicolumn{4}{|l|}{ Underlying diseases } \\
\hline Previous ischemic heart disease, (n) \% & $88(26.75)$ & $65(21.67)$ & 0.138 \\
\hline Previous MI, n (\%) & $49(14.89)$ & $31(10.33)$ & 0.087 \\
\hline Previous CABG, $\mathrm{n}(\%)$ & $11(3.34)$ & $8(2.67)$ & 0.624 \\
\hline Previous PCI, n (\%) & $40(12.16)$ & $24(8.00)$ & 0.085 \\
\hline Previous stroke/TIA, n (\%) & $13(3.95)$ & $17(5.67)$ & 0.313 \\
\hline
\end{tabular}

$\mathrm{MS}=$ metabolic syndrome; $\mathrm{SD}$ = standard deviation; $\mathrm{BMI}=$ body mass index; $\mathrm{ACS}$ = acute coronary syndrome; $\mathrm{MI}=$ myocardial infarction; NSTEMI = non-ST-segment elevation myocardial infarction CABG = coronary artery bypass graft; STEMI = ST-segment elevation myocardial infarction; $\mathrm{PCI}=$ percutaneous coronary intervention; $\mathrm{UA}=$ unstable angina; TIA = transient ischemic attack; Values are expressed as n, number of subjects, $(\%)$, percentage of subjects, unless otherwise specified 
Both in MS and non-MS group males were dominant (65.65\% vs. $71.67 \%, \mathrm{p}=0.105)$, the ratio men/women was $1.9: 1$, respectively $2.5: 1$. The mean age of MS patients was smaller compared to patients without MS (63.56 \pm 9.39 years vs. $66.91 \pm 10.34$ years, $\mathrm{p}<$ $0.001)$. In the Ms group the majority of patients were aged between 51 - 70 years $(57.14 \%)$, meanwhile in the opposite group, most patients were between 61 80 years old $(54.33 \%)$.

Cardiovascular risk factors

According to the analysis of risk factors for ACS, obesity was reported in $394(62.64 \%)$ patients, dyslipidaemia in $515(81.87 \%)$ patients, hypertension in $377(59.93 \%)$ patients and diabetes in $206(32.75 \%)$ patients. Table II presents the prevalence of metabolic syndrome components in all patients with acute coronary syndrome. In the MS group, obesity was present in all patients, followed by dyslipidaemia and hypertension (95.44\% and $77.81 \%$, respectively). Compared to patients without MS, MS group had significantly higher prevalence of obesity, diabetes mellitus, hypertension and dyslipidaemia $(100.00 \%$ vs. $21.67 \%$, $51.07 \%$ vs. $12.67 \%, 77.81 \%$ vs. $40.33 \%$, $95.44 \%$ vs. $67.00 \%$ ), and an insignificantly higher prevalence of renal failure (31.00\% vs. $24.33 \%)$. Another lipid disorder, low HDLc, was present in $84.49 \%$ of MS patients compared to a lower percentage observed in non-MS patients $(48.66 \%)$. No significant differences were observed between the 2 groups by smoking and alcohol consumption $(17.33 \%$ vs. $15.81 \%, \mathrm{p}=0.609$, respectively $5.00 \%$ vs. $3.95 \%, \mathrm{p}=0.524)$.

Table II

Prevalence of metabolic syndrome components in patients with acute coronary syndrome

\begin{tabular}{|c|c|c|c|}
\hline Components of MS & With MS $(n=329)$ & Without MS $(n=300)$ & p-value \\
\hline Obesity & $329(100.00)$ & $65(21.67)$ & $<0.001$ \\
\hline Grade 1 (BMI 30.0 - 34.9). n (\%) & $248(75.38)$ & $59(19.67)$ & $<0.001$ \\
\hline Grade 2 (BMI 35.0 - 39.9). n (\%) & $55(16.72)$ & $5(1.67)$ & $<0.001$ \\
\hline Grade $3(\mathrm{BMI}>=40) . \mathrm{n}(\%)$ & $26(7.90)$ & $1(0.33)$ & $<0.001$ \\
\hline Raised blood pressure & 291(88.44) & $205(68.33)$ & $<0.001$ \\
\hline Systolic blood pressure (mmHG). mean \pm SD & $146.53 \pm 18.66$ & $134.31 \pm 16.46$ & $<0.001$ \\
\hline Diastolic blood pressure (mmHG). mean \pm SD & $83.44 \pm 9.66$ & $79.07 \pm 9.77$ & $<0.001$ \\
\hline Previous blood pressure-lowering therapy. n (\%) & $185(72.27)$ & $79(65.29)$ & $<0.001$ \\
\hline Diabetes & $168(51.07)$ & $38(12.67)$ & $<0.001$ \\
\hline Insulin dependent DM. n (\%) & $113(67.26)$ & $27(71.05)$ & $<0.001$ \\
\hline Non-insulin-dependent DM. n (\%) & $55(32.74)$ & $11(28.95)$ & $<0.001$ \\
\hline Lipid abnormalities & $314(95.44)$ & $166(55.33)$ & $<0.001$ \\
\hline Low HDLc. n (\%) & $278(84.49)$ & $146(48.66)$ & $<0.001$ \\
\hline $\mathrm{HDLc}(\mathrm{mg} / \mathrm{dL})$. mean $\pm \mathrm{SD}$ & $34.46 \pm 5.67$ & $44.19 \pm 9.36$ & $<0.001$ \\
\hline Hypertriglyceridemia. n (\%) & $233(70.82)$ & $38(12.67)$ & $<0.001$ \\
\hline Triglycerides $(\mathrm{mg} / \mathrm{dL})$. mean $\pm \mathrm{SD}$ & $228.86 \pm 58.51$ & $110.24 \pm 33.72$ & $<0.001$ \\
\hline Previous lipid-lowering therapy. n (\%) & $84(34.86)$ & $61(62.25)$ & $<0.001$ \\
\hline
\end{tabular}

MS = metabolic syndrome; $\mathrm{SD}=$ standard deviation; $\mathrm{BMI}=$ body mass index; $\mathrm{DM}=$ diabetes mellitus; HDLc $=$ high-density lipoprotein cholesterol; Values are expressed as n, number of subjects, $(\%)$, percentage of subjects, unless otherwise specified

\section{Type of ACS}

NSTEMI was diagnosed in almost equal percentages in patients with and without MS $(33.13 \%$ vs. $33.67 \%$, $\mathrm{p}=0.866)$, unstable angina was significantly more frequent in patients with MS (33.43\% vs. $25.67 \%, \mathrm{p}=$ 0.034), and STEMI was insignificantly more frequent in patients without MS (40.67\% vs. $33.43 \%)$.

Underlying diseases

According to the analysis of underlying diseases, pre-existing cardiovascular disease was recorded in $30.70 \%$ of patients with MS and in $27.34 \%$ of patients without MS ( $p=0.225)$. In both groups the most common was previous ischemic heart disease, (26.75\% vs. $21.67 \%, \mathrm{p}=0.138)$. There were statistically significant differences in previous MI $(\mathrm{p}=0.087)$ and PCI ( $\mathrm{p}=0.085)$ between groups.

ACS treatment management strategies

The rates of reperfusion therapies in MS and nonMS patients are shown in Figure 1. Fibrinolysis strategy was applied in an insignificantly higher percentage in patients without MS $(0.66 \%$ vs. $0.61 \%$, $\mathrm{p}=0.583)$. Invasive therapy was applied in most patients $(60.89 \%)$, PCI was performed in most MS patients $(61.09 \%$ vs. $56.00 \%, \mathrm{p}=0.196)$ and $\mathrm{CABG}$ in 11 patients with MS and in 3 patients without MS (3.34\% vs. $1.00 \%, \mathrm{p}=0.047)$. Conservative strategy was approached in more in non-MS patients (43.33\% vs. $34.04 \%)$. 


\section{Treatment management strategies}

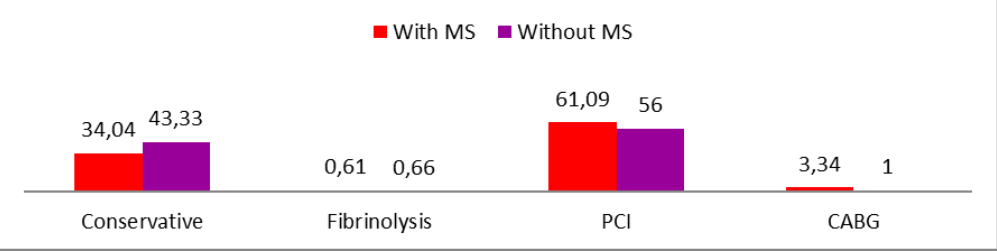

Figure 1.

ACS treatment management strategies

$\mathrm{MS}=$ metabolic syndrome; $\mathrm{PCI}=$ percutaneous coronary intervention $; \mathrm{CABG}=$ coronary artery bypass graft

Acute coronary syndrome drug regimens

A comparative analysis of patients with and without metabolic syndrome by patterns of drug use was performed. Table III presents the drug regimens used in ACS patients with and without MS during hospitalization and at discharge based on types of ACS. The regimen of ASA + clopidogrel/ticagrelor + $\beta$-blocker + ACE-I/ARB + statin was prescribed to
$311(49.44 \%)$ patients with ACS. Specifically, this regimen was used in $181(55.02 \%)$ patients with MS and in $130(43.33 \%)$ patients without MS. In both groups, the most used drugs were statins (97.87\% vs. $95.33 \%, \mathrm{p}=0.077)$, acetylsalicylic acid (95.44\% vs. $91.33 \%, \mathrm{p}=0.037)$ and ACE inhibitors (78.72\% vs. $70.00 \%, \mathrm{p}=0.012)$.

Table III

Prescription patterns for the five guideline medications for acute coronary syndrome

\begin{tabular}{|c|c|c|}
\hline Regimen & With MS (n = 329) & Without MS $(\mathrm{n}=\mathbf{3 0 0})$ \\
\hline Monotherapy, n (\%) & $1(0.30)$ & $7(2.33)$ \\
\hline ASA, n (\%) & $1(0.30)$ & $5(1.67)$ \\
\hline Clopidogrel, n (\%) & 0 & $2(0.66)$ \\
\hline Multiple therapy, n (\%) & $328(99.70)$ & $293(97.67)$ \\
\hline Double therapy, n (\%) & $5(1.52)$ & $15(5.00)$ \\
\hline ASA + Clopidogrel, n (\%) & $1(0.30)$ & $1(0.33)$ \\
\hline $\mathrm{ASA}+\mathrm{ACE}-\mathrm{I} / \mathrm{ARB}, \mathrm{n}(\%)$ & $3(0.91)$ & $4(1.33)$ \\
\hline ASA + Statin, n (\%) & 0 & $3(1.00)$ \\
\hline Clopidogrel + Statin, n (\%) & 0 & $7(2.33)$ \\
\hline Statin + Ticagrelor, n $(\%)$ & $1(0.30)$ & 0 \\
\hline Triple therapy, $\mathbf{n}(\%)$ & $53(16.11)$ & $50(16.67)$ \\
\hline ASA + Clopidogrel + Statin, n (\%) & $25(7.60)$ & $25(8.33)$ \\
\hline ASA + ACE-I/ARB + Statin, n (\%) & $3(0.91)$ & $5(1.67)$ \\
\hline ASA + Statin + Ticagrelor, $\mathrm{n}(\%)$ & $10(3.04)$ & $10(3.33)$ \\
\hline ASA $+\beta$-blocker + ACE-I/ARB, n $(\%)$ & $1(0.30)$ & $1(0.33)$ \\
\hline ASA $+\beta$-bloker + Statin, $\mathrm{n}(\%)$ & $4(1.22)$ & $1(0.33)$ \\
\hline Clopidogrel + ACE-I/ARB + Statin, n (\%) & $3(0.91)$ & $3(1.00)$ \\
\hline$\beta$-blocker + Clopidogrel + ACE-I/ARB, n (\%) & $1(0.30)$ & 0 \\
\hline$\beta$-blocker + Clopidogrel + Statin, n (\%) & $5(1.52)$ & $5(1.67)$ \\
\hline$\beta$-blocker + Statin + Ticagrelor, $\mathrm{n}(\%)$ & $1(0.30)$ & 0 \\
\hline Quadruple therapy, n (\%) & $89(27.05)$ & $98(32.67)$ \\
\hline ASA + Clopidogrel + ACE-I/ARB + Statin, n (\%) & $27(8.21)$ & $24(8.00)$ \\
\hline ASA + ACE-I/ARB + Statin + Ticagrelor, n (\%) & $25(7.60)$ & $25(8.33)$ \\
\hline ASA $+\beta$-blocker + Clopidogrel + ACE-I/ARB, n $(\%)$ & $2(0.61)$ & $1(0.33)$ \\
\hline ASA $+\beta$-blocker + Clopidogrel + Statin, $n(\%)$ & $12(3.65)$ & $18(6.00)$ \\
\hline ASA $+\beta$-blocker + ACE-I/ARB + Statin, n $(\%)$ & $9(2.74)$ & $5(1.67)$ \\
\hline ASA $+\beta$-blocker + Statin + Ticagrelor, $\mathrm{n}(\%)$ & $13(3.95)$ & $16(5.33)$ \\
\hline$\beta$-blocker + Clopidogrel + ACE-I/ARB + Statin, n (\%) & $1(0.30)$ & $8(2.67)$ \\
\hline$\beta$-blocker + ACE-I/ARB + Statin + Ticagrelor, n (\%) & 0 & $1(0.33)$ \\
\hline Quintuple therapy, n (\%) & $181(55.02)$ & $130(43.33)$ \\
\hline ASA $+\beta$-blocker + Clopidogrel + ACE-I/ARB + Statin, $n(\%)$ & $65(19.76)$ & $42(14.00)$ \\
\hline ASA + $\beta$-blocker + ACE-I/ARB + Statin + Ticagrelor, n $(\%)$ & $116(35.26)$ & $88(29.33)$ \\
\hline
\end{tabular}

MS =metabolic syndrome; ASA = acetylsalicylic acid; ACE-I = angiotensin-converting enzyme inhibitor; ARB = angiotensin II receptor blocker; Values are expressed as n, number of subjects, (\%), percentage of subjects, unless otherwise specified 
Overall, 311 (49.44\%) of 629 patients with ACS received all five guideline-recommended medications during hospitalization and at discharge from the hospital. In particular, $621(98.72 \%)$ patients were treated with over 2 drug combinations. Of them, the numbers of patients with MS and without MS who received two, three, four and five drug combinations were $5(1.52 \%)$ vs. $15(5 \%), 53(16.11 \%)$ vs. 50 (16.67\%), $89(27.05 \%)$ vs. $98(32.67 \%)$ and 181 $(55.02 \%) v s .130(43.33 \%)$, respectively.

Double therapy was used in a significant higher percentage in non-MS group (5\% vs. $1.52 \%$ ), the most frequent combination being clopidogrel + statin $(2.33 \%)$, meanwhile the less frequent consisted in acetylsalicylic acid + clopidogrel $(0.33 \%)$.

Triple therapy was used in a higher percentage in both MS and non-MS group than double therapy ( $16.11 \%$ vs. $1.52 \%$ in MS group, $16.67 \%$ vs. $5 \%$ in non-MS group). Double antiplatelet therapy (ASA + clopidogrel/ticagrelor) associated with statin was the most frequent combination in both MS and non-MS patients $(10.64 \%$ vs. $11.66 \%)$. In these combinations, clopidogrel was used in more patients with and without MS than ticagrelor (50 vs. 20 patients). Statin made part of all triple regimens used in non-MS patients (100\% vs. $98.11 \%$ in MS group) and ACEI/ARB was equally used in both MS and non-MS patients. Betablockers were used in a higher percentage among MS patients receiving triple therapy $(3.64 \%$ vs. $2.33 \%$ ).

Quadruple therapy was the second most used therapy in MS and non-MS patients, with a higher prevalence in non-MS group (32.67\% vs. 27.05\%). The most frequent drug association among MS patients was ASA + clopidogrel + ACE-I/ARB + statin (8.21\%), meanwhile in non-MS patients ASA + ticagrelor + ACE-I/ARB + statin was the most used combination $(8.33 \%)$. Regarding other combinations, they were all used in a significant higher percentage in nonMS patients $(16.34 \%$ vs. $11.24 \%)$. In particular, betablockers were given to half of non-MS patients who received quadruple therapy (50\% vs. $41.57 \%$ ), and ACE-I/ARB to $65.30 \%$ of these patients ( $v s$. $71.91 \%$ in MS patients).

In contrast with quadruple therapy, quintuple therapy was most used in MS patients (55.02\% vs. 43.33\%). Ticagrelor was the most used antiplatelet agent among MS patients receiving all five drug combinations (35.26\% ticagrelor vs. $19.76 \%$ clopidogrel). All in all, quintuple therapy is the most frequent drug combination used in both MS and non-MS patients (55.02\% in MS group and $43.33 \%$ in non-MS group).

Descriptive analysis of clinical outcomes by patterns of drug use

A comparative analysis of patients with and without Metabolic Syndrome by patterns of drug use was made (Figure 2). Mortality was unequally spread among patients with and without MS (Figure 3). There were $85(13.51 \%)$ deaths during hospitalization and at 1 year of follow up, a higher mortality rate was observed in non-MS patients (15.33\% vs. $11.85 \%)$. Deaths occurred predominantly in patients who received triple therapy, both in MS and non-MS group (4.55\% vs. $5.66 \%$ ).

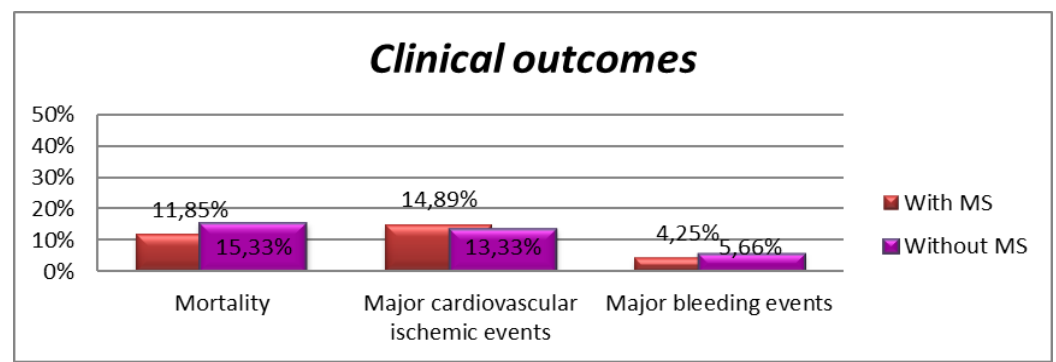

Figure 2.

Clinical outcomes of ACS patients with and without MS

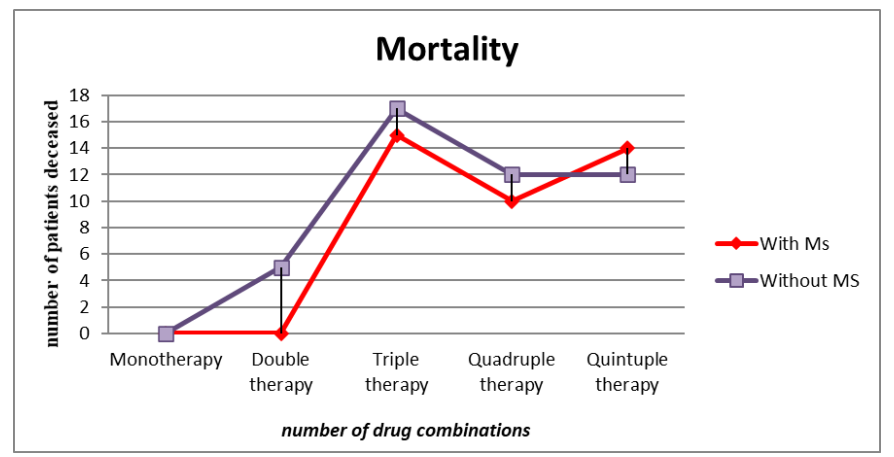

Figure 3.

Descriptive analysis of mortality rates by patterns of drug use 
Lower death rates were observed in patients receiving five drug associations (4.25\% in MS group vs. $4.00 \%$ in non-MS group) and four drug associations (3.03\% in MS group vs. $4.00 \%$ in non-MS group). An insignificant number of deaths occurred in patients receiving double therapy ( $1.66 \%$ in non-MS group) and no deaths were observed in monotherapy patients. Ischemic complications occurred in a significant higher percentage in MS patients (14.89\% vs. 13.33\%).
Major ischemic events increased statistically with the number of drug combinations (Figure 4) and were more frequently seen in patients receiving quintuple therapy, both in MS and non-MS group ( $8.81 \%$ and $6.33 \%$, respectively). Cardiovascular event rates among MS and non-MS patients receiving four, three and two drug combinations were $3.95 \%$ vs. $4.33 \%$, $2.12 \%$ vs. $2.00 \%, 0 \%$ vs. $0.66 \%$, respectively.

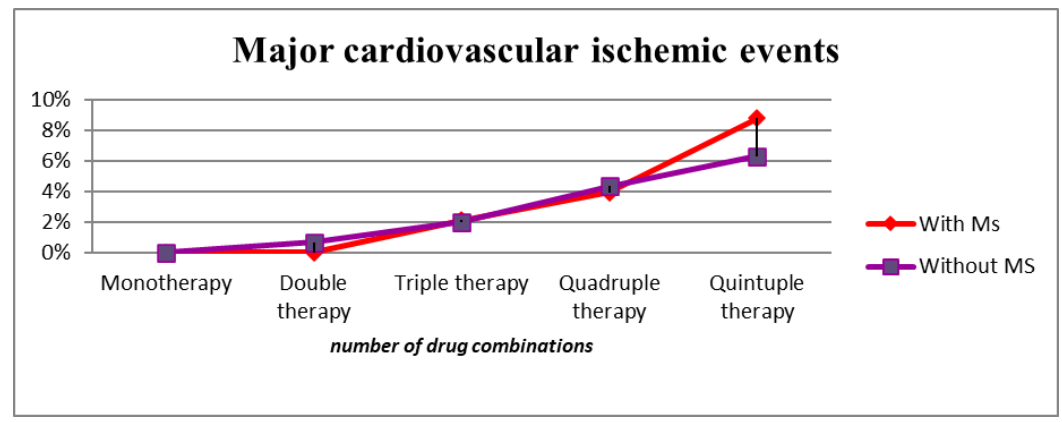

Figure 4.

Descriptive analysis of cardiovascular ischemic rates by patterns of drug use

In contrast with ischemic events, bleeding events (Figure 5) were more frequent in non-MS patients (5.66\% vs. $4.25 \%)$. An important statistically significant difference was observed among MS and non-MS patients who were treated with five $(2.43 \%$ vs. $1.33 \%)$ and four drug combinations $(0.30 \%$ vs. $2.00 \%)$. More bleeding events were observed in MS group among patients receiving five drug combinations $(2.43 \%)$, meanwhile in non-MS group the patients receiving quadruple therapy were more affected $(2.00 \%)$.

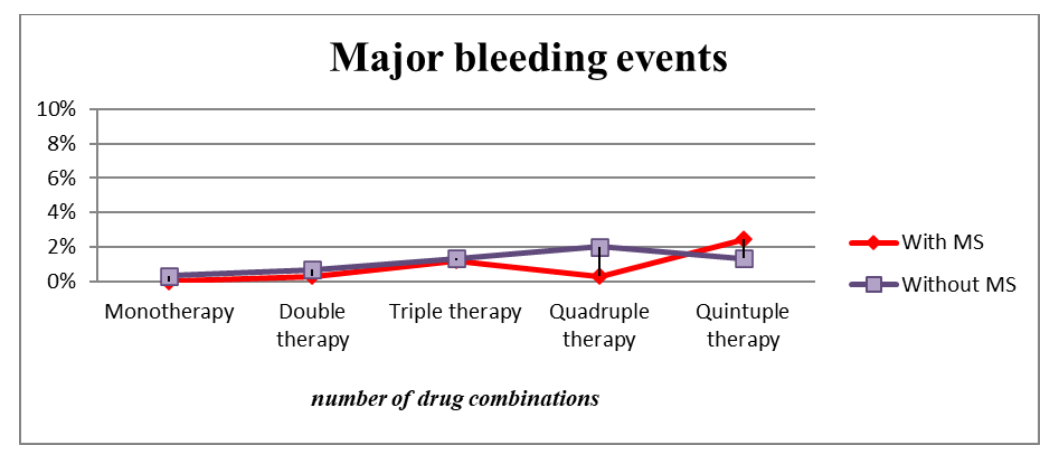

Figure 5.

Descriptive analysis of bleeding rates by patterns of drug use

This study provides information on descriptive epidemiology, practice patterns and outcomes of patients with ACS and MS in a specialized cardiac centre in Bihor County. Furthermore, a comparative analysis of patients with and without metabolic syndrome by patterns of drug use was performed. We observed similar demographic and CAD risk profiles to the previous reports from other European nations. The present study found that patients with ACS had a high prevalence of MS (52.30\%). This percentage is similar to that described in other populations with atherosclerotic vascular disease. The reported incidence of metabolic syndrome among patients with an acute coronary syndrome varies between 29 and 50\% [10]. The fact that the prevalence of MS is higher in populations with ACS than in the general population demonstrates the association between MS and ischemic heart disease. As other studies showed, the prevalence of MS is greater in men than in women in the general population [19]. Our study suggests that MS is more prevalent in men than in women even among patients with ACS $(65.65 \%$ vs. $34.35 \%$ ), which is similar to the results obtained in other populations with ischemic heart disease. Also, the mean age of MS patients was statistically smaller compared to patients without MS (63.56 \pm 9.39 years vs. $66.91 \pm 10.34$ years, $\mathrm{p}<0.001)$. MS increases cardiovascular risks and each of its components is associated with an increased risk of cardiovascular disease. Recent studies have shown 
FARMACIA, 2021, Vol. 69, 3

that MS does not increase cardiovascular risk more than the sum of its components $[14,26]$. Central obesity undoubtedly plays an important role in insulin resistance associated with MS [18]. Our findings in patients with ACS suggest that central obesity is strongly associated with coronary heart disease. These data are in agreement with previous studies, which showed that central obesity was the most important cardiovascular risk factor [3]. Obesity contributes to insulin resistance, a metabolic abnormality that precedes the development of type 2 diabetes. The presence of diabetes mellitus increases the risk for cardiovascular diseases and was observed in over $50 \%$ of patients with MS in our study. However, other components of MS were strongly associated with CAD. Furthermore, previous studies demonstrated that MS increases the risk for cardiovascular diseases, even in the absence of type 2 diabetes [17, 27]. Nevertheless, most studies supported diabetes mellitus as an independent predictor for the extent and severity of angiographic score [11]. In our study, the presence of the low HDLc and hypertension was associated with the highest risk of CAD. Beside obesity, which was the main criteria for metabolic syndrome, low HDLc levels (84.49\%) and hyperglycaemia $(70.82 \%)$ were the most prevalent components of MS, followed by hypertension. In recent studies, this was also the most frequent combination observed in patients with ischemic heart disease $[16,24]$. The prevalence of the atherogenic dyslipidaemia in our cohort was similar to that found in other studies $[6,10,22]$. Also, the high prevalence of hypertension among MS patients was in agreement with previous studies, which showed that hypertension might contribute to this group's increased postinfarction mortality. Despite this, hypertension is considered a moderate predictor for death in long-term follow-up after ACS [12, 21].

According to the ACS guidelines [7, 8], acetylsalicylic acid, $\beta$-blockers, and statins are recommended for life, whereas ACE-I/ARB are recommended in ACS patients with heart failure and reduced left ventricular (LV) ejection fraction $(<40 \%)$, diabetes, or chronic kidney disease. The ACS guidelines also recommend P2Y12 inhibitors in addition to acetylsalicylic acid for 12 months, irrespective of the stent type, depending on individual clinical judgment driven by the patient's ischaemic and bleeding risk, the occurrence of adverse events, comorbidities, co-medications and availability of the respective drugs. Approximately $50 \%$ of ACS patients included in this study received all five guideline-recommended medications during hospitalization and at discharge from the hospital. This level was lower than those found in other similar studies, where over $65 \%$ of ACS patients were discharged with the guideline-recommended medications for ACS secondary prevention [25]. Other studies also reported higher rates (over 71\%) of ACS patients discharged with maximum drug therapy [23].
However, this study applied a different definition about an optimal medication therapy for secondary prevention after ACS. It was defined as prescribing any four medications of the following: acetylsalicylic acid, P2Y12 inhibitor, ACE-I/ARB inhibitor, $\beta$-blocker, or statin/lipid-lowering agent starting the moment of hospital admission. Consequently, if the definition used in our study was applied, the rate may be expected to be lower than other studies observed. On the other hand, large variations have been reported in the extent of noncompliance in individual patients and large populations. Previous regional medication adherence research revealed the importance of therapeutic patient education for patient compliance in North-Western Romania [15].

The use of antithrombotic agents is recommended in order to reduce the rates of morbidity and mortality in patients with ACS. In this study, ASA was the antithrombotic agent most frequently prescribed, followed by ticagrelor (48.64\%) and clopidogrel (43.08\%), with a higher rate among MS patients (95.47\% vs. 91.33\%). Acetylsalicylic acid is recommended indefinitely in all patients with ACS without absolute contraindications. For long-term prevention, antithrombotic therapy was indicated. Antithrombotic monotherapy (ASA or clopidogrel) was used in few patients without MS and fewer with MS $(2.33 \%$ vs. $0.30 \%$ ). Dual antiplatelet therapy combining ASA and P2Y12inhibitor (ticagrelor or clopidogrel) is recommended in patients with ACS who underwent primary PCI (for up to 12 months) or fibrinolytic therapy. ASA and clopidogrel combination was the therapy applied in $132(40.12 \%)$ MS patients and in $111(37.00 \%)$ non-MS patients, demonstrating the need of MS patients for more intensive drug therapy and more invasive procedures (e.g PCI or CABG). ASA and ticagrelor was similarly used in ACS patients, with a higher prevalence in MS subjects (49\% vs. $46.33 \%)$.

The benefits of statins in secondary prevention have been unequivocally demonstrated, and according to the ESC guidelines [7, 8], an early and intensive statin therapy was applied. Statins were the most used drugs, both in MS and non-MS patients $(97.87 \%$ vs. $95.33 \%, \mathrm{p}=0.077)$. In patients at increased risk of side effects from statins (e.g. elderly, hepatic or renal impairment, previous side effects, or a potential for interaction with essential concomitant therapy) or with history of intolerance to high-intensity statin therapy and other characteristics that may influence safety patients, other treatments were considered (e.g. ezetimibe). Over $78 \%$ of MS patients received ACE-I or ARB, but no more than $70 \%$ of patients without MS. ACE inhibitors were recommended in all patients with systolic LV dysfunction or heart failure, hypertension, or diabetes and whose hemodynamic status allowed. Other clinical study reports on the regional prevalence of prescription ACE 
inhibitors among patients with ischemic heart disease revealed similar results [13]. Patients who do not tolerate an ACE inhibitors were given angiotensin II receptor blockers (ARB).

All patients without contraindications received betablockers $(70.21 \%$ of MS patients vs. $62.33 \%$ of nonMS patients). The benefit of long-term treatment with oral beta-blockers after ACS is well established in terms of mortality reduction. Beta-blockers are recommended in patients with reduced systolic LV function $(<40 \%)$, in the absence of contraindications such as acute heart failure, haemodynamic instability, or higher degree AV block.

$98.72 \%$ of patients were treated with over 2 drug combinations and $49.44 \%$ of them received all five guideline-recommended medications during hospitalization and at discharge from the hospital. Quintuple therapy was most used in MS patients (55.02\% vs. $43.33 \%)$ probably because these patients had more cardiovascular risk factors that required medication. Double therapy was used in a higher percentage in non-MS group (5\% vs. $1.52 \%)$, triple therapy was used equally in both MS and non-MS group (16.11\% vs. $16.67 \%)$, quadruple therapy had a higher prevalence in non-MS group $(32.67 \%$ vs. $27.05 \%$ ) and quintuple therapy was most used in MS patients $(55.02 \%$ vs. $43.33 \%)$. As the number of drug therapy components increases, more and more MS patients benefited from it. This fact demonstrates that MS patients have more associated medical conditions that require intensive medication.

The 1-year mortality rate observed in the current report is higher than the values in most multicentre registries. It is however comparable to the findings in some single centre-based studies. The influence of hospital setting has also an influence on ACS outcomes, centres having $24 \mathrm{~h}$ coronary care unit, cardiac catheterization and cardiac surgery services had lower mortality $[1,2]$. A higher mortality rate has been observed among patients without MS (15.33\% vs. $11.85 \%), 32 \%$ of total deaths occurred during hospitalization for the ACS and $67 \%$ of deceased patients died after hospital discharge. An equal number of MS and non-MS patients died during hospitalization for the ACS, meaning that discharge medication had an important role in rate mortality among these patients. Long-term survival of MS patients with ACS in the era of intervention revascularization and high-precision medicine is still uncertain. Several studies have reported that MS is associated with poor survival in ACS patients, meanwhile others showed no difference in terms of survival according to the presence of MS [28]. The lower mortality rate of MS patients enrolled in the present study is probably due to the fact that these patients had multiple modifiable cardiovascular risk factors such as hypertension, diabetes, dyslipidaemia, obesity, factors that were influenced by the guideline long-term drug therapies applied for the acute coronary syndrome. Deaths occurred predominantly in patients who received less medication. Lower death rates were observed in MS patients receiving four or five drug associations ( $3.03 \%$ and $4.25 \%$, respectively), meanwhile patients with less medication had the higher mortality rate $(4.55 \%)$. These results sustain the benefits of long-term drug therapy in terms of mortality reduction. Furthermore, invasive therapy (PCI and CABG) was performed in most MS patients (64.43\% vs. 57.00), reperfusion therapy being the most important in the event of ACS.

Major cardiovascular ischemic events, including coronary events and stroke, were more frequently seen in patients having MS and receiving multiple drug therapy (14.89\% vs. $13.33 \%)$. We observed similar major coronary events among MS subject in previous reports [4]. The higher rates observed among MS subjects are probably because these patients had more complex and severe coronary artery disease. In some patients standard surgical or percutaneous interventions were no longer available due to its complexity. Moreover, these patients had also more diabetes, dyslipidaemia, hypertension, hardly controlled even by intensive medication. Despite MS patients had higher rates of ischemic events, there have been significant lower mortality rates in this study group. Major bleeding events were less frequent among MS patients $(4.25 \%$ vs. $5.66 \%)$. In this group, more events were observed among patients receiving five drug combinations $(2.43 \%)$, which, actually, was the most frequent drug combination used in these patients (55.02\% in Ms group vs. $43.33 \%$ in non-MS group). This percentage is similar to that described in other ACS cohorts investigated for the incidence of post-discharge bleeding [5]. In fact, MS patients who had quintuple therapy as discharge medication had the highest bleeding rate among all subjects included in this study. These data are as a result of long-term multiple medication, including dual antiplatelet therapy (acetylsalicylic acid in combination with clopidogrel or ticagrelor) more frequently used in MS study group. Antiplatelet drugs are known to be associated with an increased bleeding risk, whatever the dual antiplatelet regimen that can lead to more major bleeding events.

\section{Conclusions}

This study provides information on practice patterns and outcomes of patients with ACS and MS, throughout a comparative analysis of patients with and without metabolic syndrome by patterns of drug use. The majority of ACS patients included in this study received all five long-term guideline-recommended medications for acute coronary syndrome. According to the European Society of Cardiology guidelines for the management of acute coronary syndrome, 
Acetylsalicylic Acid, P2Y12 inhibitors statins, $\beta$ blockers and ACE-I/ARB are the long-term therapies recommended to reduce recurrence of ischemic cardiovascular events and to improve the quality of life in patients with ACS. Since the study on medication patterns and their follow-up assessments after ACS treatment among MS patients has been rarely conducted in Romania, it is meaningful in that this study could be useful in identifying the gaps between recommended and prescribed ACS medications and 1-year outcomes in patients with MS. It is also necessary to perform more studies about the outcomes of ACS patients according to the prescription patterns of those medications for ACS secondary prevention in the near future.

\section{Conflict of interest}

The authors declare no conflict of interest.

\section{References}

1. Arbel Y, Havakuk O, Halkin A, Revivo M, Berliner S, Herz I, Weiss-Meilik A, Sagy Y, Keren G, Finkelstein A, Banai S, Relation of Metabolic Syndrome With Long-Term Mortality in Acute and Stable Coronary Disease. Am J Cardiol., 2015; 115(3): 283-287.

2. Bahiru E, Agarwal A, Berendsen MA, Baldridge AS, Temu T, Rogers A, Farquhar C, Bukachi F, Huffman MD, Hospital-Based Quality Improvement Interventions for Patients With Acute Coronary Syndrome: A Systematic Review. Circ Cardiovasc Qual Outcomes, 2019; 12(9): e005513: 1-19.

3. Barroso T, Marins L, Alves R, Gonçalves A, Barroso S, Souza Rocha G, Association of Central Obesity with The Incidence of Cardiovascular Diseases and Risk Factors. Int J Cardiovasc Sci., 2017; 30: 416424

4. Cavallari I, Cannon CP, Braunwald E, Goodrich EL, Im K, Lukas MA, O'Donoghue ML, Metabolic syndrome and the risk of adverse cardiovascular events after an acute coronary syndrome. Eur J Prev Cardiol., 2018; 25(8): 830-838

5. Chhatriwalla AK, Amin AP, Kennedy KF, House JA, Cohen DJ, Rao SV, Messenger JC, Marso SP; National Cardiovascular Data Registry, Association between bleeding events and in-hospital mortality after percutaneous coronary intervention. JAMA, 2013; 309(10): 1022-1029.

6. Ciavoi G, Tirb A, Bechir ES, Bechir F, Suciu I, Effects of Smoking and Lipid Profile of the Patient on the Onset and Maintenance of Periodontal Disease. Rev Chim., 2018; 69(10): 2648-2651.

7. Collet JP, Thiele H, Barbato E, Barthélémy O, Bauersachs J, Bhatt DL, Dendale P, Dorobantu M, Edvardsen T, Folliguet T, Gale CP, Gilard M, Jobs A, Jüni P, Lambrinou E, Lewis BS, Mehilli J, Meliga E, Merkely B, Mueller C, Roffi M, Rutten FH, Sibbing D, Siontis GCM; ESC Scientific Document Group, 2020 ESC Guidelines for the management of acute coronary syndromes in patients presenting without persistent ST-segment elevation: The Task Force for the management of acute coronary syndromes in patients presenting without persistent ST-segment elevation of the European Society of Cardiology (ESC). Eur Heart J., 2021, 42(14): 1289-1367.

8. Ibanez B, James S, Agewall S, Antunes MJ, BucciarelliDucci C, Bueno H, Caforio A, Crea F, Goudevenos J, Halvorsen S, Hindricks G, Kastrati A, Lenzen MJ, Prescott E, Roffi M, Valgimigli M, Varenhorst C, Vranckx P, Widimský P, ESC Scientific Document Group, ESC Guidelines for the management of acute myocardial infarction in patients presenting with ST-segment elevation: The Task Force for the management of acute myocardial infarction in patients presenting with ST-segment elevation of the European Society of Cardiology (ESC), Eur Heart J., 2018, 39(2): 119-177.

9. Jelavic MM, Babic Z, Pintaric H, Metabolic syndrome: influence on clinical severity and prognosis in patients with acute ST-elevation myocardial infarction treated with primary percutaneous coronary intervention. Acta Cardiologica, 2015; 70(2): 149-156

10. Jovera A, Corbellab E, Muñozc A, Millánd J, Pintób X, Mangase A, Zúñigaf M, Botetg JP, HernándezMijares A, Prevalence of Metabolic Syndrome and its Components in Patients With Acute Coronary Syndrome. Rev Esp Cardiol., 2011; 64(7): 579-586.

11. Kim JJ, Hwang BH, Choi IJ, Choo EH, Lim S, Kim JK, Koh YS, Kim DB, Jang SW, Cho EJ, Lee JM, Kim PJ, Cho JH, Jung JI, Seung KB, Min JK, Chang K, Impact of diabetes duration on the extent and severity of coronary atheroma burden and longterm clinical outcome in asymptomatic type 2 diabetic patients: evaluation by Coronary CT angiography. Eur Heart J Cardiovasc Imaging, 2015; 16(10): 1065-1073.

12. Konstantinou K, Tsioufis C, Koumelli A, Mantzouranis M, Kasiakogias A, Doumas M, Tousoulis D, Hypertension and patients with acute coronary syndrome: Putting blood pressure levels into perspective. J Clin Hypertens., 2019; 21(8): 1135-1143.

13. Maghiar F, Vicaș LG, Ardelean A, Teușdea A, Țica OA, Oros C,Mureșan ME, Retrospective study on angiotensin-converting-enzyme inhibitors treatment, Farmacia, 2020; 68(1): 90-96.

14. Mente A, Yusuf S, Islam S, McQueen MJ, Tanomsup S, Onen CL, Rangarajan S, Gerstein HC, Anand SS; INTERHEART Investigators, Metabolic syndrome and risk of acute myocardial infarction. A casecontrol study of 26,903 subjects from 52 countries. J Am Coll Cardiol., 2010; 55(21): 2390-2398.

15. Moisa C, Vlad AM, Teușdea A, Cadar O, Hoaghia MA, Stan RL, Tăerel A, Jurca C, Vicaș LG, Randomized evaluation on the consumption of antibiotics in community pharmacies. Farmacia, 2018; 66(6): 1081-1090.

16. Nolan PB, Carrick-Ranson G, Stinear JW, Reading SA, Dalleck LC. Prevalence of metabolic syndrome and metabolic syndrome components in young adults: A pooled analysis. Prev Med Rep., 2017; 7: 211-215.

17. Nsiah K, Shang VO, Boateng KA, Mensah FO, Prevalence of metabolic syndrome in type 2 diabetes mellitus patients. Int J Appl Basic Med Res., 2015; 5(2): 133-138. 
18. O'Neill S, O'Driscoll L, Metabolic syndrome: a closer look at the growing epidemic and its associated pathologies. Obes Rev., 2015; 16(1): 1-12.

19. Ostaptchouk VV, Nuotio ML, Slagter SN, Doiron D, Fischer K, Foco L, Gaye A, Gögele M, Heier M, Hiekkalinna T, Joensuu A, Newby C, Pang C, Partinen E, Reischl E, Schwienbacher C, Tammesoo ML, Swertz MA, Burton P, Ferretti V, Fortier I, Giepmans L, Harris JR, Hillege HL, Holmen J, Jula A, KootstraRos JE, Kvaløy K, Holmen TL, Männistö S, Metspalu A, Midthjell K, Murtagh MJ, Peters A, Pramstaller PP, Saaristo T, Salomaa V, Stolk RP, Uusitupa M, van der Harst $P$, van der Klauw MM, Waldenberger M, Perola M, Wolffenbuttel BH, The prevalence of metabolic syndrome and metabolically healthy obesity in Europe: A collaborative analysis of ten large cohort studies. BMC Endocr Dis., 2014; 14: 9: 1-13.

20. Popa S, Moţa M, Popa A, Moţa E, Serafinceanu C, Guja C, Catrinoiu D, Hâncu N, Lichiardopol R, Bala C, Popa A, Roman G, Radulian G, Timar R, Mihai B, Prevalence of overweight/obesity, abdominal obesity and metabolic syndrome and atypical cardiometabolic phenotypes in the adult Romanian population: PREDATORR study. J Endocrinol Invest., 2016; 39(9): 1045-1053.

21. Paul E, Radovanovic D, Schoenenberger AW, Bertel O, Kaeslin T, Essig M, Gaspoz JM; AMIS Plus Investigators, Impact of hypertension on outcome of patients admitted with acute coronary syndromes. Journal of Hypertension, 2015; 33: 860-867.

22. Ramón-Arbués E, Martínez-Abadía B, Gracia-Tabuenca T, Yuste-Gran C, Pellicer-García B, Juárez-Vela R, Guerrero-Portillo S, Sáez-Guinoa M, [Prevalence of overweight/obesity and its association with diabetes, hypertension, dyslipidemia and metabolic syndrome: a cross-sectional study of a sample of workers in Aragón, Spain]. Nutr Hosp., 2019; 36(1): 51-59.

23. Redfern J, Hyun K, Chew DP, Astley C, Chow C, Aliprandi-Costa B, Howell T, Carr B, Lintern K, Ranasinghe I, Nallaiah K, Turnbull F, Ferry C, Hammett C, Ellis CJ, French J, Brieger D, Briffa T, Prescription of secondary prevention medications, lifestyle advice, and referral to rehabilitation among acute coronary syndrome inpatients: results from a large prospective audit in Australia and New Zealand. Heart, 2014; 100: 1281-1288.

24. Saklayen MG, The Global Epidemic of the Metabolic Syndrome. Curr Hypertens Rep., 2018; 20(2): 12: $1-8$.

25. Tra J, Van der Wulp I, Appelman Y, de Bruijne MC, Wagner $\mathrm{C}$, Adherence to guidelines for the prescription of secondary prevention medication at hospital discharge after acute coronary syndrome: A multicenter study. Neth Heart J., 2015; 23: 214-221.

26. Tune JD, Goodwill AG, Sassoon DJ, Mather KJ, Cardiovascular consequences of metabolic syndrome. Transl Res., 2017; 183: 57-70.

27. Walther G, Obert P, Dutheil F, Chapier R, Lesourd B, Naughton G, Courteix D, Vinet A, Metabolic syndrome individuals with and without type 2 diabetes mellitus present generalized vascular dysfunction: cross-sectional study. Arterioscler Thromb Vasc Biol., 2015; 35(4): 1022-1029.

28. Won KB, Kim BK, Chang HJ, Shin DH, Kim JS, Ko YG, Choi D, Ha JW, Hong MK, Jang Y, Metabolic syndrome does not impact long-term survival in patients with acute myocardial infarction after successful percutaneous coronary intervention with drug-eluting stents. Catheter Cardiovasc Interv., 2014; 83(5): 713-720. 